\title{
Physiological Role of Humic Acid and Nicotinamide on Improving Plant Growth, Yield, and Mineral Nutrient of Wheat (Triticum durum) Grown under Newly Reclaimed Sandy Soil
}

\author{
Hala Safwat Mohamed El-Bassiouny', Bakry Ahmed Bakry2 ${ }^{*}$, Amany Abd El-Monem Attia ${ }^{1}$, \\ Maha Mohamed Abd Allah ${ }^{1}$ \\ ${ }^{1}$ Botany Department, Agriculture and Biology Division, National Research Center, Cairo, Egypt \\ ${ }^{2}$ Agronomy Department, Agriculture and Biology Division, National Research Center, Cairo, Egypt \\ Email: Bakry ahmed2004@yahoo.com
}

Received 12 May 2014; revised 28 June 2014; accepted 13 July 2014

Copyright (C) 2014 by authors and Scientific Research Publishing Inc.

This work is licensed under the Creative Commons Attribution International License (CC BY).

http://creativecommons.org/licenses/by/4.0/

(c) (i) Open Access

\begin{abstract}
Humic acid is not a fertilizer as it does not directly provide nutrients to plants, but is a compliment to fertilizer. Nicotinamide (Vitamin pp) is a stress-associated compound that can induce and regulate secondary metabolic accumulation and/or the manifestation of defense metabolism in plants. A field experiment was conducted at the experimental station of National Research center at El-Nubaria region, Egypt, to study the role of foliar application of humic acid (as soil conditioner $13 \mathrm{~cm} / \mathrm{l}$ ) and/or priming grains in nicotinamide (vitamin pp $5 \mathrm{mg} / \mathrm{l}$ ) in saving irrigation water, decreasing fertilizer dose of NPK and at the same time increasing durum wheat (Triticum durum) cultivars' (Beni Sweif-1 and Beni Sweif-3) productivity grown under newly reclaimed sandy soil exposed to drought for three weeks continuously. The results showed that plant treated with humic acid or nicotinamide increased significantly all morphological criteria (plant height, leaves number, fresh and dry weights of shoots), metabolism (photosynthetic pigment, total soluble sugar, total carbohydrates, total amino acids and proline), mineral contents ( $\mathrm{N}, \mathrm{P}, \mathrm{K}, \mathrm{Ca}$ and $\mathrm{Mg}$ ) and yield (grain, straw and biology) of both cultivars amended with either recommended or half recommended doses of NPK. Foliar application of humic acid to plant priming in Vitamin pp induced significant increases in all studied parameters (morphology, chemical and yield) of plants amended with recommended or half recommended doses of NPK as compared with control plants. The maximum yields of grain, straw and biology of both cultivars were obtained in response to triple treatment (humic acid + nicotinamide + recommended dose of NPK) or (humic acid + nicotinamide + half recommended dose of NPK) respectively.
\end{abstract}

*Corresponding author.

How to cite this paper: El-Bassiouny, H.S.M., Bakry, A.B., Abd El-Monem Attia, A. and Abd Allah, M.M. (2014) Physiological Role of Humic Acid and Nicotinamide on Improving Plant Growth, Yield, and Mineral Nutrient of Wheat (Triticum durum) Grown under Newly Reclaimed Sandy Soil. Agricultural Sciences, 5, 687-700. http://dx.doi.org/10.4236/as.2014.58072 


\section{Keywords}

\section{Humic Acid, Metabolism, Mineral Ions, Nicotinamide, Wheat}

\section{Introduction}

One of the most crucial functions of plant cells is their ability to respond to fluctuations in their environment. Understanding the connections between a plant's initial responses and the downstream events that constitute successful adjustment to its altered environment is one of the next grand challenges of plant biology.

Wheat is the most widely grown food crop in the world. In Egypt, wheat is one of the most important winter crop; it occupies over $27 \%$ of total cultivated area. Its production is about 7.5 million tons per year (Ministry of Agriculture, Egypt 2010). The balance between the production and consumption of wheat represented about $40 \%$ of the national demands imported from foreign markets. For these reasons efforts should be directed toward increasing and improving the wheat yield, in order to fill the gap between production and consumption; thus the cultivated area outside the Nile Valley and the Delta could be increased by reclaimed new lands.

The new reclaimed sandy soil in Egypt is considered as a part of the Sahara Desert of Northern Africa, which is exposed to a combination of environmental stress conditions including temperature fluctuations, low water availability, high irradiance, and nutrient deprivation. In these areas the water is the major factor limiting plant growth. This water stress may be alleviated by irrigation whenever possible or saved irrigation water by using certain bioregulators as antioxidants and soil conditioners as humic acid. Such stress may lead to reduce plant growth by affecting various physiological and biochemical processes, such as photosynthesis, respiration, translocation, ion uptake, carbohydrates, nutrient metabolism and growth promoters [1].

Humic acids are materials that promote plant growth and improve yield [2]. It is particularly used to ameliorate or reduce the negative effect of stress [3]. It may have both direct and indirect effects on the plant growth [4]. Indirect effects involve improvements of the soil properties such as aggregation, aeration, permeability, water holding capacity, micronutrient transport and availability [5] [6]. Direct effects are those, which require uptake of humic substances into the plant tissue resulting in various biochemical effects [7]. The importance of bio-stimulants lies in their ability to promote hormonal activity in plants as well as promote antioxidant production in plants which, in turn, reduces free radicals. It increased root vitality, improved nutrient uptake, increased chlorophyll synthesis, better seed germination and increased fertilizer retention [8]. Humic acid reduces the amount of fertilizer consumption, and makes plant tolerant against stress, drought stress. Also, production of total plant increases yield, and reinforces the plant stem as well [9].

Nicotinamide is a stress-associated compound that induces and regulates secondary metabolic accumulation and/or the manifestation of defense metabolism in plants [10].

The target of this work is to increase the efficiency of growth and productivity of wheat cultivars grown under environmental stresses (drought) to overcome this stress, reduce the amount of fertilizer consumption and increase wheat yield quantitatively and qualitatively. So, we can use some vitamins (Nicotinamide) as precursor for producing the most active constituents as bioregulators to alleviate the harmful effect.

\section{Materials and Methods}

A field experiment was carried out at the experimental Station of National Research Centre, Nubria district ElBehrea Governorate-Egypt, during the two successive winter seasons of 2011/2012 and 2012/2013. The soil of both of our experiments sites were Newly Reclaimed sandy soil where mechanical and chemical analysis is reported in Table 1 according to [11] method.

Location and climate of experimental site: this experimental farm (latitude $30^{\circ} 30^{\prime} 1.4 \mathrm{~N} \mathrm{~N}$, and longitude $30^{\circ} 19^{\prime} 10.9^{\prime \prime E}$, and mean altitude $21 \mathrm{~m}$ above sea level). The data of maximum and minimum temperature, relative humidity, and wind speed were obtained from "Local Weather Station inside El-Nubaria Farm" is reported in Table 2.

The aim of this work was to increase the efficiency of growth and productivity of two wheat cultivars (Beni Sweif-1 [V1] and Beni Sweif-3 [V2]) grown under environmental stresses. So, we use humic acid, and (Nicotinamide) as precursor for producing the most active constituents as bioregulators to alleviate the harmful effect of 
Table 1. Chemical and mechanical analyses of soil of our experimental sites.

\begin{tabular}{|c|c|c|c|c|c|c|c|c|}
\hline \multirow{2}{*}{ Depth } & \multicolumn{4}{|c|}{ Chemical analysis } & \multicolumn{3}{|c|}{ Mechanical analysis } & \multirow{2}{*}{ Texture } \\
\hline & OM (\%) & $\mathrm{pH}(1: 2.5)$ & EC $\left(\mathrm{d} \cdot \mathrm{Sm}^{-1}\right)$ & $\mathrm{CaCO}_{3 \%}$ & Course sand & Fine sand & Clay + Silt & \\
\hline $0-20$ & 0.65 & 8.7 & 0.35 & 7.02 & 47.76 & 49.75 & 2.49 & \\
\hline $20-40$ & 0.40 & 8.8 & 0.32 & 2.34 & 56.72 & 39.56 & 3.72 & Sandy \\
\hline $40-60$ & 0.25 & 9.3 & 0.44 & 4.68 & 36.76 & 59.40 & 3.84 & \\
\hline Depth & \multicolumn{2}{|c|}{ SP (\%) } &.$C(\%)$ & W.P (\%) & A.W (\%) & \multicolumn{3}{|c|}{ Hydraulic conductivity (cm/hr) } \\
\hline $0-20$ & \multicolumn{2}{|c|}{21.0} & 10.1 & 4.7 & 5.4 & \multicolumn{3}{|c|}{22.5} \\
\hline $20-40$ & \multicolumn{2}{|c|}{19.0} & 13.5 & 5.6 & 7.9 & \multicolumn{3}{|c|}{19.0} \\
\hline $40-60$ & \multicolumn{2}{|c|}{22.0} & 12.5 & 4.6 & 7.9 & & 21.0 & \\
\hline
\end{tabular}

Table 2. Meteorological data for Nubaria region in 2011/012 and 2012/013 growing seasons.

\begin{tabular}{ccccc}
\hline & \multicolumn{5}{c}{$\mathbf{2 0 1 1 / 2 0 1 2}$ Season } & \\
\hline Month & $\mathrm{T} \max \left({ }^{\circ} \mathrm{C}\right)$ & $\mathrm{T} \min \left({ }^{\circ} \mathrm{C}\right)$ & $\mathrm{WS}(\mathrm{m} / \mathrm{s})$ & $\mathrm{RH}(\%)$ \\
\hline November & 21.70 & 11.10 & 0.23 & 81.90 \\
December & 19.60 & 7.80 & 0.17 & 85.60 \\
January & 17.01 & 7.42 & 0.90 & 81.10 \\
February & 16.40 & 7.70 & 0.60 & 79.70 \\
March & 21.86 & 8.65 & 0.61 & 80.36 \\
April & 27.08 & 12.10 & 0.58 & 74.40 \\
November & 14.44 & $\mathbf{2 0 1 2} / \mathbf{2 0 1 3}$ Season & & \\
December & 20.99 & 25.71 & 0.34 & 90.30 \\
January & 18.79 & 9.94 & 0.64 & 82.94 \\
February & 20.89 & 7.24 & 0.65 & 89.71 \\
March & 24.36 & 7.90 & 0.60 & 83.29 \\
April & 25.98 & 9.98 & 0.75 & 76.58 \\
\hline
\end{tabular}

T $\max =$ Maximum temperature; $\mathrm{T}$ Min = Minimum temperature; WS = Wind speed; $\mathrm{RH}=$ Relative humidity.

sandy soil and recommended (R) or half recommended (1/2R) dose of NPK (75:31:48) (37.5:15.5:24) fertilization in forms of ammonium nitrate $(33.5 \% \mathrm{~N})$, calcium superphosphate $\left(15.5 \% \mathrm{P}_{2} \mathrm{O}_{5}\right)$ and potassium sulfate $\left(48 \% \mathrm{~K}_{2} \mathrm{O}\right)$ were applied under newly reclaimed sandy soil. The experimental design was split plot design with four replicates. Which wheat cultivars occupy the main plots and treatments of (1/2R, R, 1/2R + Humic, $R+$ Humic, 1/2R + Nicotinamide, $R+$ Nicotinamide, $1 / 2 R+$ Humic + Nicotinamide, $R+$ Humic + Nicotinamide) were allocated at random in sub-plots. Grains of wheat cultivars were sown on the 15 November in both season in rows 4 meters long, the distance between rows was $25 \mathrm{~cm}$ apart, Plot area was $12 \mathrm{~m}$ (3.0 $\mathrm{m}$ in width and $4.0 \mathrm{~m}$ in Length). Irrigation was carried out using the new sprinkler irrigation system where water was added every 5 days. wheat plants were foliar sprayed with Humic acid at the rate of $(13 \mathrm{mg} / \mathrm{L})$. In both seasons, foliar application of Humic acid was carried out twice; where plants were sprayed after 45 and 60 days from sowing. Skipping the irrigation at 45 and 60 days after sowing after sprayed Humic acid.

Seeds of the wheat cultivars (Beni Sweif-1 [V1] and Beni Sweif-3 [V2] were taken from Agricultural Research Centre, Egypt. Soaking of seeds of the two cultivars was for $12 \mathrm{~h}$ in nicotinamide concentrations $5 \mathrm{mg} / \mathrm{l}$. Plant samples were taken after 75 days from sowing for measurements growth characters were measured in terms of, plant height shoots fresh and dry weight, roots length, root fresh and dry weight. Plant samples were taken for 
chemical analysis after 75 days from sowing for measurements of photosynthetic pigments, total IAA and total phenol contents total soluble sugars, total carbohydrates, proline, free amino acids, total protein. At harvest stage, the mean values of yield and yield characters, i.e., plant height, spike length $(\mathrm{cm})$, number of spikes/plant, weight of spikes/plant (g), grain index (100-grain weight (g)), grain, straw and biological yield per plant (g) and per fed.

\subsection{Photosynthetic Pigments}

Total chlorophyll a and $\mathrm{b}$ and carotenoids contents in fresh leaves were estimated using the method of [12].

The fresh tissue was ground in a mortar and pestles using $80 \%$ acetone. The optical density (OD) of the solution was recorded at 662, 645 and $470 \mathrm{~nm}$ (for chlorophyll a, b and carotinoids) using a spectrophotometer (Shimadzu UV-1700, Tokyo, Japan).

\subsection{Indole Acetic Acid}

A known weight of the fresh samples was taken and extracted with $85 \%$ cold methanol $(\mathrm{v} / \mathrm{v})$ for three times at $0^{\circ} \mathrm{C}$. Then take $1 \mathrm{ml}$ of the methanolic extract and $4 \mathrm{ml}$ of PDAB reagent (para-dimethylamino benzoic acid $1 \mathrm{~g}$ dissolve in $50 \mathrm{ml} \mathrm{HCl}, 50 \mathrm{ml}$ of ethanol 95\%) and left for $60 \mathrm{~min}$ in $30^{\circ} \mathrm{C}-40^{\circ} \mathrm{C}$. The developing colour was spectophotometrically measured at wave length of $530 \mathrm{~nm}$ as described by [13].

\subsection{Total Phenol}

A known weight of the fresh samples of shoots were taken and extracted with $85 \%$ cold methanol (v/v) for three times at $0^{\circ} \mathrm{C}$. Then $0.5 \mathrm{ml}$ of the extraction was added to $0.5 \mathrm{ml}$ Folin, shaken allowed to stand for $3 \mathrm{~min}$. Then one $\mathrm{ml}$ of saturated sodium carbonate was added to each tube followed by distilled water shaken and allowed to stand for $60 \mathrm{~min}$. The optical density was determined at wave length of $725 \mathrm{~nm}$ using spectrophotometer as described by [14].

\subsection{Total Soluble Sugars (TSS)}

Total soluble carbohydrates (TSS) were extracted by overnight submersion of dry tissue in $10 \mathrm{ml}$ of $80 \%$ (v/v) ethanol at $25^{\circ} \mathrm{C}$ with periodic shaking, and centrifuged at $600 \mathrm{~g}$. The supernatant was evaporated till completely dried then dissolved in a known volume of distilled water to be ready for determination of soluble carbohydrates [15]. TSS were analyzed by reacting of $0.1 \mathrm{ml}$ of ethanolic extract with $3.0 \mathrm{ml}$ freshly prepared anthrone (150 $\mathrm{mg}$ anthrone $+100 \mathrm{ml} 72 \% \mathrm{H}_{2} \mathrm{SO}_{4}$ ) in boiling water bath for ten minutes and reading the cooled samples at $625 \mathrm{~nm}$ using Spekol Spectrocololourimeter VEB Carl Zeiss [16].

\subsection{Total Carbohydrate}

Determination of total carbohydrates was carried out according to [17]. A known mass (0.2 - $0.5 \mathrm{~g}$ ) of dried tissue was placed in a test tube, and then $10 \mathrm{ml}$ of sulphuric acid $(1 \mathrm{~N})$ was added. The tube was sealed and placed overnight in an oven at $100^{\circ} \mathrm{C}$. The solution was then filtered into a measuring flask (100 ml) and completed to the mark with distilled water. The total sugars were determined colorimeterically according to the method of [18] as follows: An aliquot of $1 \mathrm{ml}$ of sugar solution was transferred into test tube and treated with $1 \mathrm{ml}$ of $5 \%$ aqueous phenol solution followed by $5 \mathrm{ml}$ of concentrated sulphuric acid. The optical density of the developed color was measured at $490 \mathrm{~nm}$ using Shimadzu spectrophotometer model UV 1201.

\subsection{Proline}

Proline was assayed according to the method described by [19]. Two $\mathrm{ml}$ of proline extract, $2 \mathrm{ml}$ of acid ninhydrin and $2 \mathrm{ml}$ of glacial acetic acid were added and incubated for $1 \mathrm{~h}$ in a boiling water bath followed by an ice bath. The absorbance was measured at $520 \mathrm{~nm}$ using Spekol Spectrocololourimeter VEB Carl Zeiss. A standard curve was obtained using a known concentration of authentic proline.

\subsection{Free Amino Acids}

Free amino acid content was extracted according to the method described by [20]. Free amino acid was determined with the ninhydrin reagent method [21]. One ml acetate buffer (pH 5.4) and $1 \mathrm{ml}$ chromogenic agent were 
added to $1 \mathrm{ml}$ free amino acid extraction. The mixture was heated in boiling water bath for $15 \mathrm{~min}$ after cooled in tap water, $3 \mathrm{ml}$ ethanol $(60 \% \mathrm{v} / \mathrm{v})$ was added. The absorbance at $570 \mathrm{~nm}$ was then determined using Spekol Spectrocololourimeter VEB Carl Zeiss.

\subsection{Total Protein}

Total protein concentration of the supernatant was determined according to the method described by [22] with bovine serum albumin as a standard. An amount of $2 \mathrm{gm}$ of samples were grinded in mortar with $5 \mathrm{ml}$ of phosphate buffer ( $\mathrm{pH}$ 7.6) and was then transformed to the centrifuge tubes. The homogenate was centrifuged at $8000 \mathrm{rpm}$ for 20 minutes. The supernatant of different samples were made equal by adding phosphate buffer solution. After extraction, $30 \mu \mathrm{l}$ of different samples were mixed with $70 \mu \mathrm{l}$ of distilled water separately. In all of these separate sample tubes $2.9 \mathrm{ml}$ of Coosmassic Brillaint Blue solution was then added and mixed thoroughly. The Total volume now was $3 \mathrm{ml}$ in each tube. All these tubes were incubated for 5 minutes at room temperature and absorbance at $600 \mathrm{~nm}$ was recorded against the reagent blank. A standard curve of Absorbance (600 nm) versus Concentration $(\mu \mathrm{g})$ of protein was calculated.

\subsection{Mineral Ions}

Macro and microelement contents of were determined according to the method described by [11]. N and P were determined using Spekol Spectrocololourimeter VEB Carl Zeiss. While, estimation of Ca, K and Mg contents was estimated using atomic absorption spectrophotometer.

\subsection{Statistical Analysis}

The data were statistically analyzed on complete randomized design according to [23]. Means were compared by least significant difference (LSD) at 5\% levels of probability [24].

\section{Results and Discussion}

\subsection{Morphological Criteria}

Table 3 illustrates the effect of foliar spray of humic acid (HA), nicotinamide (NA) and recommended or half recommended doses of NPK on growth parameters of both wheat cultivars (Beni Sweif-1 and Beni Sweif-3). Data show that, when compared with the corresponding control without humic, the growth parameters (plant height, leaves number/plant and fresh and dry weight of shoot/plant) were significantly increased with humic acid applications. Results also show that, application of nicotinamide improved growth when compared to control. Ni-

Table 3. Effect of nicotinamide, Humic acid and fertilizer doses (recommended R) and half recommended $(1 / 2 \mathrm{R})$ ) on morphological criteria of two wheat cultivars grown under newly reclaimed sandy soils while [V1] is Beni Sweif-1 and [V2] is Beni Sweif-3 variety ( combined data of 2011/2012 and 2012/2013 seasons).

\begin{tabular}{|c|c|c|c|c|c|c|c|c|}
\hline \multirow{2}{*}{ Treatment } & \multicolumn{2}{|c|}{ Plant height cm } & \multicolumn{2}{|c|}{ Leaves No./plant } & \multicolumn{2}{|c|}{ Shoot fresh wt/g } & \multicolumn{2}{|c|}{ Shoot dry wt/g } \\
\hline & V1 & V2 & V1 & V2 & $\mathrm{V} 1$ & V2 & $\mathrm{V} 1$ & V2 \\
\hline $1 / 2 \mathrm{R}$ & 66.67 & 71.33 & 4.00 & 4.00 & 4.43 & 5.65 & 1.27 & 1.64 \\
\hline $\mathrm{R}$ & 72.67 & 68.33 & 5.00 & 4.67 & 7.50 & 6.10 & 2.00 & 1.96 \\
\hline 1/2R + Humic & 72.00 & 71.67 & 5.67 & 4.00 & 6.53 & 5.27 & 1.78 & 1.95 \\
\hline $\mathrm{R}+$ Humic & 77.67 & 70.00 & 5.00 & 4.33 & 8.20 & 6.63 & 2.17 & 2.27 \\
\hline 1/2R + Nic. & 69.00 & 73.00 & 4.67 & 5.00 & 5.77 & 6.57 & 1.57 & 1.80 \\
\hline $\mathrm{R}+$ Nic. & 77.33 & 76.33 & 5.33 & 4.67 & 7.27 & 6.87 & 1.80 & 1.67 \\
\hline 1/2R + Humic + Nic. & 78.00 & 72.67 & 5.00 & 5.33 & 9.30 & 8.20 & 2.20 & 2.00 \\
\hline R + Humic + Nic. & 78.33 & 73.00 & 5.33 & 5.00 & 10.00 & 10.80 & 2.30 & 2.43 \\
\hline LSD 0.05 & \multicolumn{2}{|c|}{3.25} & \multicolumn{2}{|c|}{0.81} & \multicolumn{2}{|c|}{1.52} & \multicolumn{2}{|c|}{0.45} \\
\hline
\end{tabular}


cotinamide increased all morphological criteria in the presence of humic acid under both recommended and half recommended doses of NPK over the corresponding untreated plant amended with recommended dose for both cultivars and the both treatments were non significantly increased. [25] mentioned that in many instances, regular humic acid use will reduce the need for fertilization due to the soil's and plant's ability to make better use of it. In some occurrences, fertilization can be eliminated entirely if sufficient organic material is present and the soil can become self sustaining through microbial processes and humus production [26]. A humic acid is considered to increase the permeability of plant membranes and enhance the uptake of nutrients. [27] found that there was increase in root and shoot lengths in the seedlings treated with potassium humate. Moreover, application of humic acid had significant effects on the growth rate on soybean plant [28].

Application of nicotinamide in the present study improved growth in the wheat plants by causing significant increases in the values of the above parameters. Similar results were obtained by [29] using nicotinamide. Our results are in agreement with [30] found that treating faba bean with nicotinamide mitigated the deleterious effect of drought on plant and improved growth and yield. Moreover, the inhibitory effects of drought were mitigated partially or completely alleviated. This is probably by protecting the photosynthetic pigments, the photosynthetic apparatus and increasing the metabolic activities relevant to growth through enhancing cell division and/or cell enlargement. These were further corroborated by the significantly higher levels of carbohydrate by vitamin treatment [30].

\subsection{Photosynthetic Pigments}

Regarding to photosynthetic pigments of wheat plant grown in newly reclaimed sandy soil is represented in (Figure 1) Data show that HA applications caused significant increases in chlorophyll a, chlorophyll b, carotenoids and total pigments of the two used cultivars (Beni Sweif-1 and Beni Sweif-3) as compared with the corresponding control treated with the recommended dose of fertilizer application in both cultivars. These results are in agreement with [31] using HAs, from a soil when various foliar applications were performed. Humic substances have positive effects on plant physiology. [32] found that a foliar application with $20 \mathrm{ppm}$ humic acid was effective on increasing of chlorophyll content. [31] also indicate that HA probably caused an increase in the synthesis of the chlorophyll and/or delayed chlorophyll degradation in the two different types of leaves, primary and lateral shoot leaves.

Nicotinamide application to wheat plants significantly increase chlorophyll a, b and carotenoid content. Similar results have been reported in tomato by [33]. The effect of nicotinamide on the biosynthesis of chlorophyll may be attributed to its activation of enzymes that regulate photosynthetic carbon reduction [34].

\subsection{Indol Acetic Acid and Phenol Content}

Figure 2, show that HA and nicotinamide increased IAA and phenol content significantly of both wheat cultivars (Beni Sweif-1 and (Beni Sweif-3) as compared with the corresponding control treated with the recommended dose of fertilizer application in both varieties. The triple treatment (humic acid + nicotinamide + recommended dose of NPK) and (humic acid + nicotinamide + half recommended dose of NPK) were the most effective treatment in both cultivars respectively (Beni Sweif-1 and Beni Sweif-3).This increase in IAA concurrent with the increase in growth rate as shown in (Table 3). It could be concluded that this increase may due to the role of endogenous hormone in stimulating cell division and/or the cell enlargement, this in turn improve plant growth and by decreasing IAA oxidase activity and promoting metabolic activities consequently accelerates growth and yield of crops [35]. Increase in phenol content in different tissues under osmotic stress has been reported in many plants [36]. This increase may be due to total phenols role to play a significant mechanism in regulation of plant metabolic processes and consequently overall plant growth [37]. Moreover, phenols act as a substrate for many antioxidants enzymes, so, it mitigates stress injuries [38]. [39] showed that HA application significantly improved antioxidant compounds in pepper fruit and this effect was mainly on carotenoids and phenolic compounds. Application of vitamins (nicotinamide) generally led to high significant increases in the values of IAA [30].

\subsection{Carbohydrate Contents}

The effect of foliar application of HA, nicotinamide and recommended or half recommended doses of $\mathrm{N}$ on the total soluble sugar, polysaccharides and total carbohydrate of the two used cultivars are shown in Figure 3. Data 

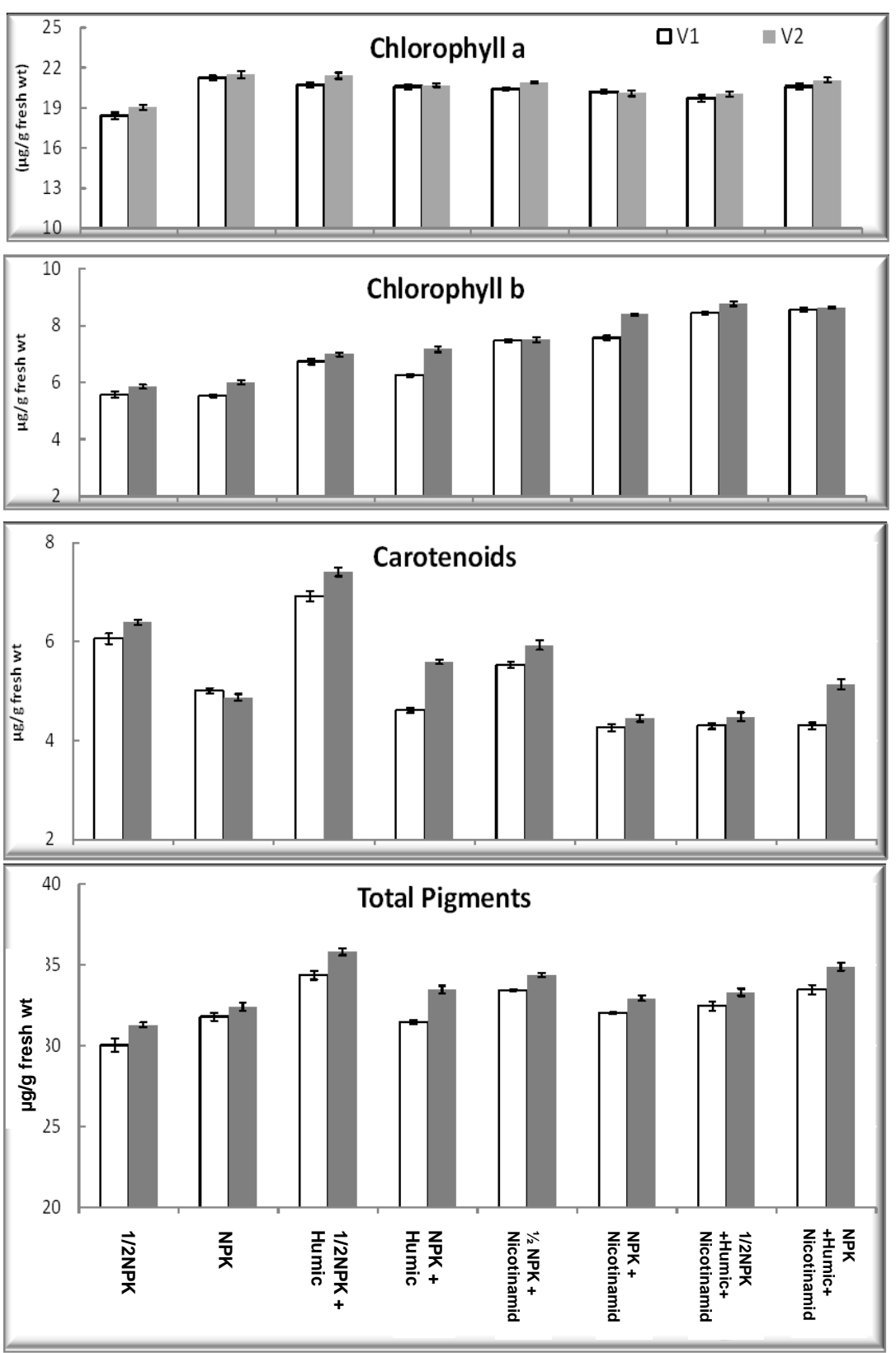

Figure 1. Effect of nicotinamide, fertilizer doses (recommended (NPK) and half recommended (1/2 NPK)) and humic acid on photosynthetic pigment contents ( $\mu \mathrm{g} / \mathrm{g}$ fresh wt) of two wheat cultivars grown under newly reclaimed sandy soils while [V1] is Beni Sweif-1 and [V2] is Beni Sweif-3 variety. LSD at 5\% chlorophyll a: 0.1; LSD at 5\% chrophyll b: 0.05 ; LSD at 5\% Carotenoids: 0.01 ; LSD at 5\% total pigments: 0.01 .

clearly show that, HA $+1 / 2$ recommended dose of NPK treatment caused significant increases in TSS, carbohydrate and polysaccharides in Beni Sweif-1 and Beni Sweif-3 variety as compared with nicotinamide treatment and that of the corresponding control plants with recommended or half recommended doses of NPK. The treatments with $(\mathrm{HA}+\mathrm{Nico}+\mathrm{R})$ \& $(\mathrm{HA}+\mathrm{Nico}+1 / 2 \mathrm{R})$ were nonsignificant different in Beni Sweif-1 were the most effective treatment in both varieties. The significant increases in total carbohydrates, in shoots of wheat cultivars concomitantly with the increased growth rate led to the conclusion that the photosynthetic efficiency was increased in response to HA treatments and thus led to enhance biosynthesis of carbohydrates which are utilized in growth of wheat plants. Similar results to our obtained results were obtained by [40]. This positive effect of HA has also been 

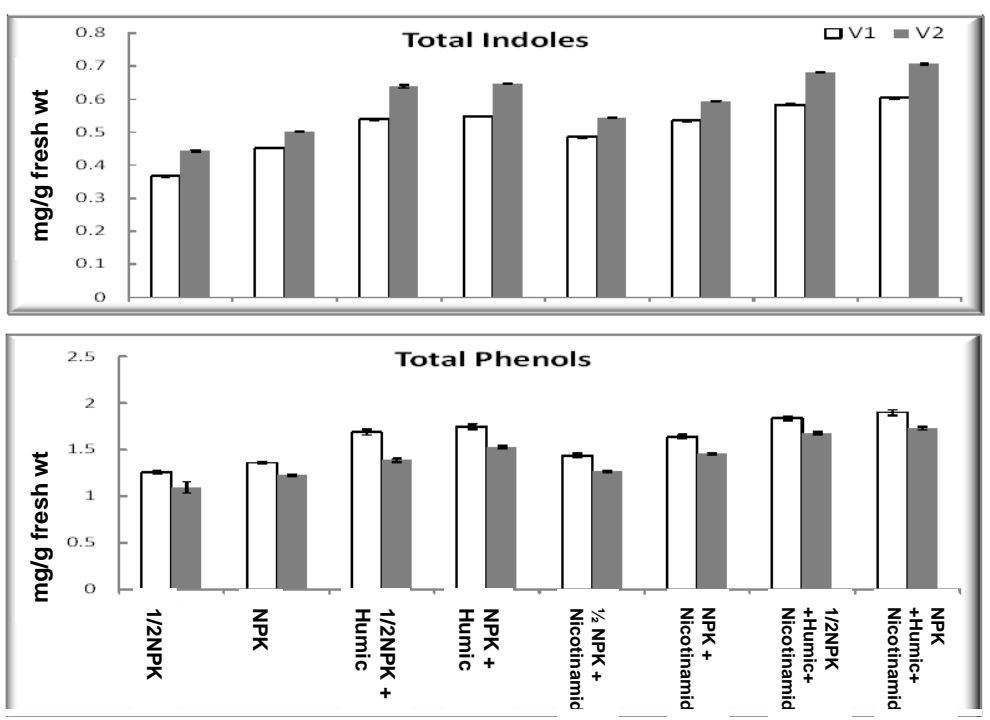

Figure 2. Effect of nicotinamide, fertilizer doses (recommended (NPK) and half recommended $(1 / 2 \mathrm{NPK})$ ) and humic acid on some chemical contents (mg/g fresh wt) of two wheat cultivars grown under newly reclaimed sandy soils while [V1] is Beni Sweif-1 and [V2] is Beni Sweif-3 variety. LSD at 5\% Total indol: 0.017; LSD at 5\% Total phenols: 0.01 .
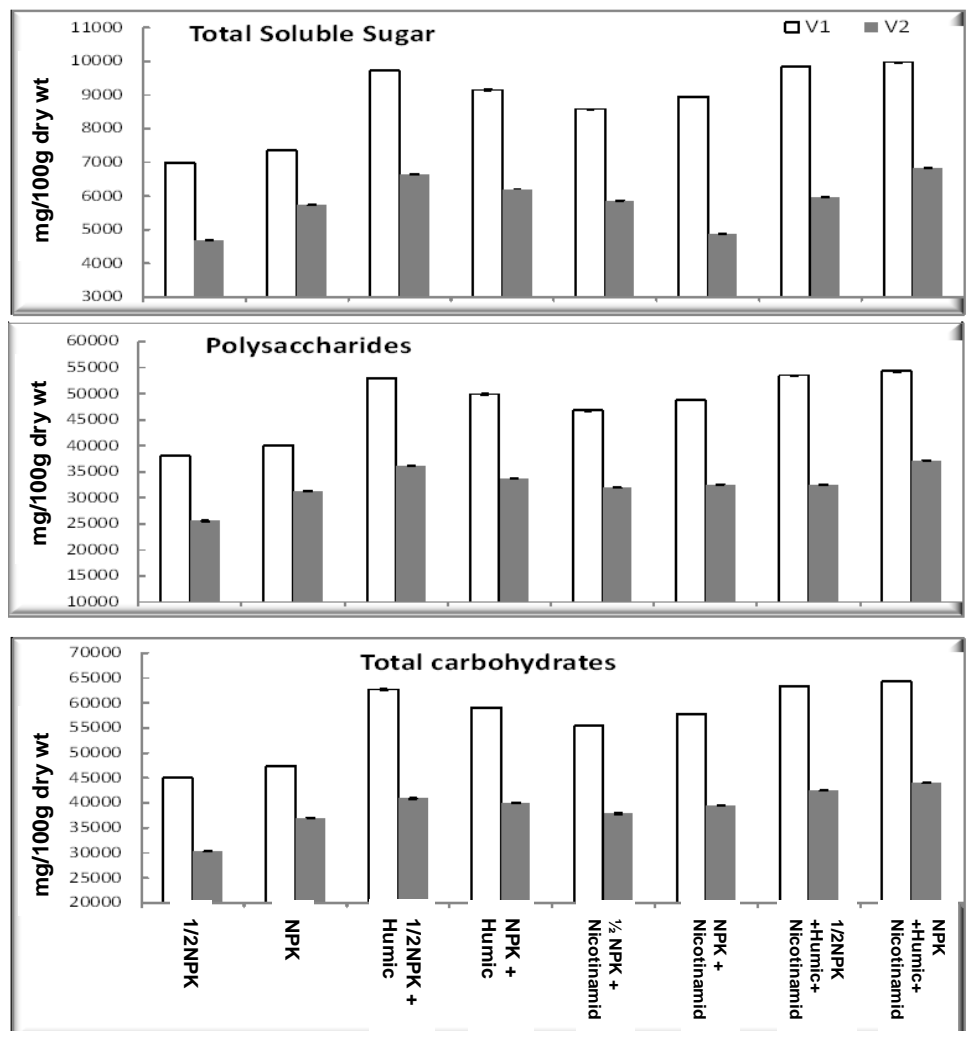

Figure 3. Effect of nicotinamide, fertilizer doses (recommended (NPK) and half recommended $(1 / 2 \mathrm{NPK})$ ) and humic acid on some chemical contents (mg/100 g dry wt) of two wheat cultivars grown under newly reclaimed sandy soils while [V1] is Beni Sweif-1 and [V2] is Beni Sweif-3 variety. LSD at 5\% Total soluble suger: 151.20; LSD at 5\% Polysaccharides: 3291.67; LSD at 5\% Total carbohydrates: 3281.95 . 
observed on the main photosynthetic metabolism in maize leaves, where a decrease in starch content was accompanied by an increase of soluble sugars [41]. This change appeared to be mediated by variations of the activity of the main enzymes involved in carbohydrate metabolism [40].

Vitamin pp application generally stimulated the accumulation of carbohydrates in the wheat plant, either via increasing endogenous levels of certain phytohormones or by acting as activators of carbohydrates synthesis [42]. The reduction in TSS in Beni Sweif-3 cultivar was suggested that nicotinamide application might activate the metabolic consumption of soluble sugars to form new cell constituents as a mechanism to stimulate the growth of wheat plants reported in this study. nicotinamide treatment might also be assumed to inhibit polysaccharide-hydrolyzing enzyme system on one hand and/or accelerate the incorporation of soluble sugars into polysaccharides.

\subsection{Proline, Total Amino Acids and Total Protein}

Data presented in Figure 4, shows that HA increased significantly proline content of wheat cultivar (Beni Sweif-1) when compared with the untreated plants, while non significant increase in( Beni Sweif-3) at 1/2 recommended + humic acid and significant decrease in recommended + humic acid. These results are in agreement with those obtained by [43] humic acid treatments decreased proline content in leaves and roots compared with control. The treatment with nicotinamide induced non significant increase in both cultivars as compared with the corresponding treatment with half recommended dose of fertilizer. However, the treatment with HA and /or nicotinamide increased significantly free amino acid contents and total protein of both wheat cultivars (Beni Sweif-1 and Beni Sweif-3) when compared with corresponding treatment with recommended dose of fertilizer. The maximum increases in free amino acids were obtained by using the treatment (nicotinamide + half recommended dose of NPK) while the maximum increases in total protein were obtained by using the treatment ((HA + Nico + R) over the untreated plant amended with recommended dose of NPK in both cultivars. These results are in agreement with those of [44]. Many functions have been postulated for proline accumulation in plant tissues, proline and free amino acids could be involved in the osmotic adjustment of plants [45] and could also be a protective agent of enzymes and membranes [46]. When plant subjected to drought stress, plants maintain their water content by accumulation of compatible organic solutes act as osmoprotectants, such as proline, in their cytoplasm [47]. Proline accumulation under drought stress has been reported and suggested to be a biochemical marker for increased stress tolerance in plant species under stress conditions. This means that the inhibitory effect of drought stress on the tested wheat plant was alleviated by vitamins treatments through increasing proline synthesis and/or enhancing the biosynthesis of other amino acids and their incorporation into protein. Finally, proline able to activate multiple responses that are component of the adaptation processes [48]. Application of vitamins (nicotinamide) in this study generally led to high significant increases in the values of total protein [30].

\subsection{Mineral Contents}

Data in Figure 5 show that, when compared with the control plant, the mineral contants (K, P, Ca, Mg and N) of both wheat cultivars (Beni Sweif-1 and Beni Sweif-3) found higher on humic acid application. The importance of bio-stimulants lies in their ability to promote hormonal activity in plants as well as promote antioxidant production in plants which, in turn, reduces free radicals. It is increase root vitality, improved nutrient uptake, [8]. Foliar applications of humic acid had a significant effect on the dry weight and mineral elements uptake in corn [49]. [50] mentioned that, the commercial humic acids were found to improve growth, yield production, quality and increased significantly in the accumulation of $\mathrm{P}, \mathrm{K}, \mathrm{Ca}, \mathrm{Mg}, \mathrm{Fe}, \mathrm{Zn}$ and $\mathrm{Mn}$ in tissues of some vegetable crops. The content of $\mathrm{K}+, \mathrm{Ca}, \mathrm{Mg}, \mathrm{N}$ and $\mathrm{P}$ of shoots significant increased by nicotinamide treatments (Figure 5). Several reports indicate that nicotinamide application increased mineral contents in different crop species [30] and [51].

\subsection{Yield and Yield Components}

Data in Table 4 illustrate the effect of foliar spray of humic acid (HA), nicotinamide (Nico) and recommended or half recommended doses of $\mathrm{N}$ on yield and its components. Data also showed that, when compared with the control treatment, the yield and its components yield of both wheat cultivars (Beni Sweif-1 and Beni Sweif-3) found significantly enhanced with foliar application of humic acid. It was noticed that yield characters for both wheat cultivars (Beni Sweif-1 and Beni Sweif-3) were increased with increasing concentration of NPK. The maximum increases in all the yield and its components were obtained by using the triple treatment (humic acid + 

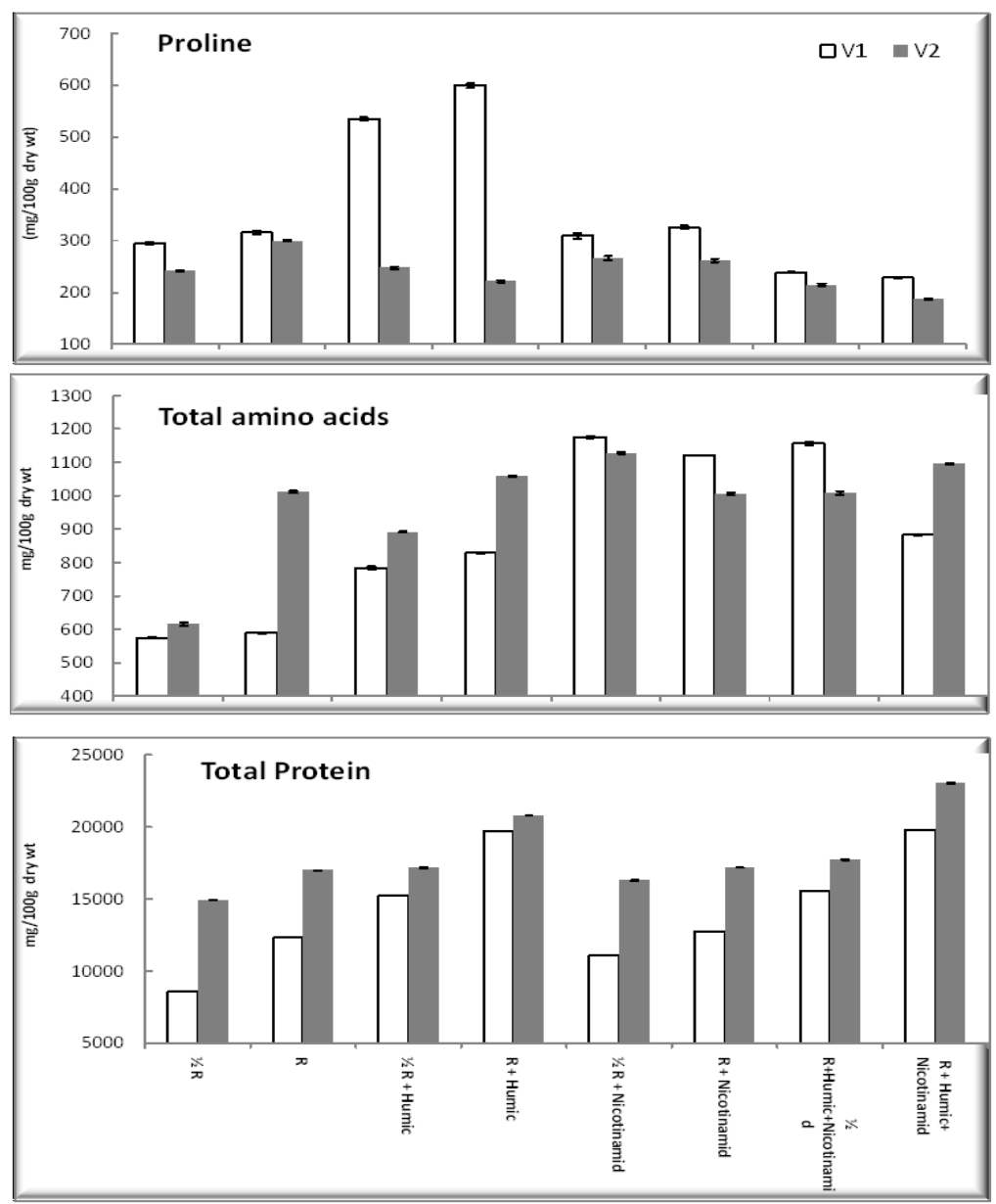

Figure 4. Effect of nicotinamide, fertilizer doses (recommended (R) and half recommended (1/2R)) and humic acid on some chemical contents (mg/100 g dry wt) of two wheat cultivars grown under newly reclaimed sandy soils. LSD at 5\% Proline: 12.41 ; LSD at 5\% Total amino acid: 569.89; LSD at 5\% Total protein: 362.16.

Table 4. Effect of nicotinamide, humic acid and fertilizer doses recommended (R) and half recommended (1/2 R) on yield and its component of two wheat cultivars grown under newly reclaimed sandy soils while [V1] is Beni Sweif-1 and [V2] is Beni Sweif-3 variety ( combined data of 2011/2012 and 2012/2013 seasons).

\begin{tabular}{|c|c|c|c|c|c|c|c|c|c|c|c|c|c|c|c|c|}
\hline \multirow{2}{*}{ Treatment } & \multicolumn{2}{|c|}{$\begin{array}{l}\text { Plant height } \\
\text { Cm }\end{array}$} & \multicolumn{2}{|c|}{$\begin{array}{l}\text { spike length } \\
\text { Cm }\end{array}$} & \multicolumn{2}{|c|}{$\begin{array}{c}\text { No. of } \\
\text { Spikelet/Spike }\end{array}$} & \multicolumn{2}{|c|}{$\begin{array}{c}1000 \text { grains } \\
\text { Weight (g) }\end{array}$} & \multicolumn{2}{|c|}{$\begin{array}{l}\text { grain yield } \\
\text { /spike (g) }\end{array}$} & \multicolumn{2}{|c|}{$\begin{array}{c}\text { Straw yield } \\
\text { (ton/fed) }\end{array}$} & \multicolumn{2}{|c|}{$\begin{array}{l}\text { Biological yield } \\
\text { (ton/fed) }\end{array}$} & \multicolumn{2}{|c|}{$\begin{array}{c}\text { grain yield } \\
\text { (ton/fed) }\end{array}$} \\
\hline & V1 & V2 & V1 & V2 & V1 & V2 & V1 & V2 & V1 & V2 & $\mathrm{V} 1$ & V2 & V1 & V2 & V1 & V2 \\
\hline $1 / 2 \mathrm{R}$ & 74.7 & 72.8 & 7.33 & 7.3 & 18.7 & 21 & 55.0 & 49.8 & 3.3 & 2.7 & 3.02 & 2.96 & 4.00 & 4.13 & 0.983 & 1.172 \\
\hline $\mathrm{R}$ & 79.3 & 77.0 & 7.67 & 7.0 & 17.3 & 19 & 56.9 & 63.3 & 3.4 & 2.8 & 3.09 & 2.89 & 4.43 & 4.33 & 1.343 & 1.442 \\
\hline $1 / 2 \mathrm{R}+$ Humic & 86.3 & 86.3 & 8.3 & 8.0 & 17.3 & 23.7 & 64.2 & 63.4 & 3.6 & 2.9 & 3.23 & 3.08 & 4.71 & 4.63 & 1.479 & 1.547 \\
\hline $\mathrm{R}+$ Humic & 86.0 & 79.0 & 9.3 & 7.7 & 20.0 & 19.0 & 64.1 & 60.7 & 3.8 & 3.0 & 3.16 & 3.04 & 4.88 & 4.75 & 1.719 & 1.710 \\
\hline $\begin{array}{c}1 / 2 \mathrm{R}+ \\
\text { Nicotinamide }\end{array}$ & 83.0 & 87.3 & 8.0 & 7.7 & 18.7 & 18.7 & 54.4 & 54.4 & 3.6 & 2.9 & 3.28 & 3.17 & 4.49 & 4.44 & 1.208 & 1.275 \\
\hline $\begin{array}{c}\mathrm{R}+ \\
\text { Nicotinamide }\end{array}$ & 80.3 & 85.0 & 8.3 & 7.0 & 20.7 & 18.3 & 74.7 & 57.0 & 3.9 & 3.3 & 3.22 & 2.97 & 4.71 & 4.95 & 1.493 & 1.619 \\
\hline $\begin{array}{c}\text { 1/2R }+ \text { Humic }+ \\
\text { Nicotinamide }\end{array}$ & 85.7 & 90.0 & 7.7 & 8.3 & 20.3 & 19.0 & 73 & 63.7 & 3.8 & 3.6 & 2.93 & 2.75 & 4.91 & 4.87 & 1.983 & 2.121 \\
\hline $\begin{array}{l}\mathrm{R}+\text { Humic }+ \\
\text { Nicotinamide }\end{array}$ & 83.0 & 87.7 & 9.0 & 8.0 & 21.0 & 20.0 & 68.5 & 65.7 & 4.2 & 3.8 & 2.83 & 2.57 & 5.14 & 5.07 & 2.312 & 2.502 \\
\hline LSD 0.05 & \multicolumn{2}{|c|}{3.62} & \multicolumn{2}{|c|}{1.4} & \multicolumn{2}{|c|}{3.58} & \multicolumn{2}{|c|}{1.94} & \multicolumn{2}{|c|}{0.91} & \multicolumn{2}{|c|}{0.38} & \multicolumn{2}{|c|}{0.35} & \multicolumn{2}{|c|}{0.175} \\
\hline
\end{tabular}



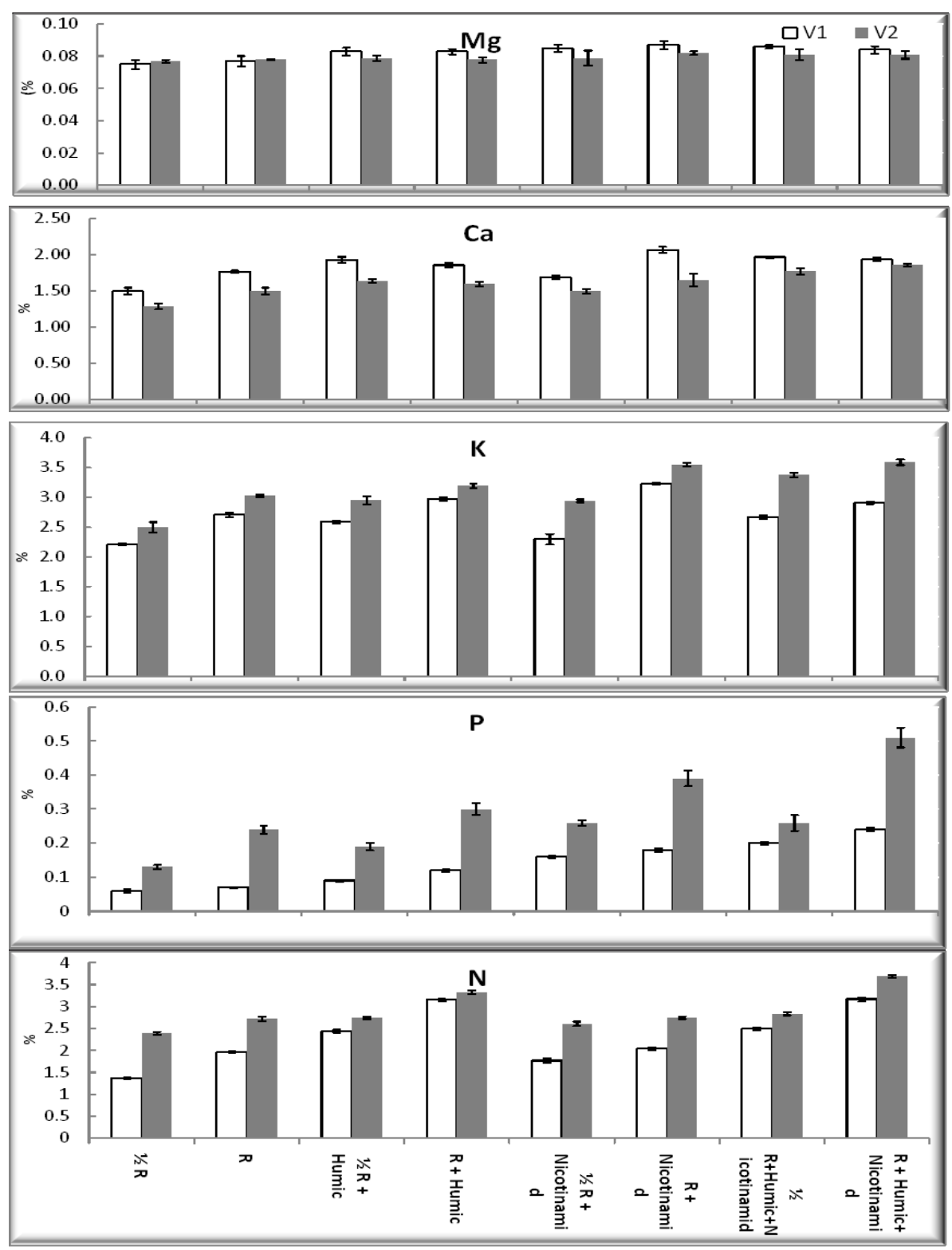

Figure 5. Effect of nicotinamide, fertilizer doses (recommended (R) and half recommended $(1 / 2 \mathrm{R})$ ) and humic acid on minerals percent (\%) of two wheat cultivars grown under newly reclaimed sandy soils. LSD at 5\% Mg: 0.02; LSD at 5\% Ca: 0.03; LSD at 5\% K: 0.05; LSD at $5 \%$ P: $0.01 ;$ LSD at $5 \%$ N: 0.01.

nicotinamide + recommended dose of NPK) and (humic acid + nicotinamide + half recommended dose of NPK) respectively over the untreated plant amended with recommended dose of NPK. Humic acid has important properties that contribute to increasing yield and yield components of wheat [52]. Results also show that, priming seeds of two cultivars by soaking it in nicotinamide improved growth and yield when compared to control. Nicotinamide increased growth and yield in the presence of humic acid under both recommended and half recommended doses of fertilizer. The increase in the growth and yield parameters of wheat in response to nicotinamide treatments relative to untreated plants might be result from the increased number of spike and grains. Increased levels of endogenous hormones in the treated plants (Figure 2) contributed to enhanced growth and yield, induced by nicotinamide. Plant growth regulators appear either to form a sink mobilizing the different nutrients, which are involved in building new tissues in the wheat plants and/or to enhance the photosynthetic mechanism and protein synthesis [53]. Similar results were obtained by [29]. 


\section{References}

[1] Jaleel, C.A., Sankar, B., Murali, P.V., Gomathinayagam, M., Lakshmananm, G.M.A. and Panneerselvam, R. (2008) Water Deficit Stress Effects on Reactive Oxygen Metabolism in Catharanthus Roseus; Impacts on Ajmalicine Accumulation. Colloids and Surfaces B: Biointerfaces, 62, 105-111. http://dx.doi.org/10.1016/j.colsurfb.2007.09.026

[2] Ayus, M., Moreno, J.L., Hernández, T. and Garcia, C. (1999) Characterisation and Evaluation of Humic Acids Extracted from Urban Waste as Liquid Fertilizers. European Journal of Soil Science, 75, I4481-I4488.

[3] Azarpour, E., Moraditochaee, M. and Bozorgi, H.R. (2012) Evaluating Energy Balance and Energy Indices of Wheat Production in Rain-Fed Farming in Northern Iran. African Journal of Agricultural Research, 7, 1950-1955.

[4] Chen, Y. and Aviad, T. (1990) Effect of Humic Substances on Plant Growth. In: Maccarthy, P., Ed., Humic Substances in Soil and Crop Sciences: Selected Readings. American Society of Agronomy and Soil Sciences, Madison, 161-186.

[5] Tan, K.H. (2003) Chemical Composition of Humic Acidmatter. In: Humic Acids in Soil and the Environment, Principles and Controversies, Marcel and Dekker, New York.

[6] Ferrara, G. and Brunetti, G. (2010) Effects of the Times of Application of a Soil Humic Acid on Berry Quality of Table Grape (Vitis vinifera L.) c.v Italia. Spanish Journal of Agricultural Research, 8, 817-822. http://dx.doi.org/10.5424/1283

[7] Nardi, S., Pizzeghello, D., Muscolo, A. and Vianello, A. (2002) Physiological Effects of Humic Substances on Higher Plants. Soil Biology and Biochemistry, 34, 1527-1536. http://dx.doi.org/10.1016/S0038-0717(02)00174-8

[8] Liu, C. and Cooper, R.J. (2000) Humic Substances Influence Creeping Bentgrass Growth. Golf Course Management, 49-53.

[9] Anonymous (2010) Humic and Fulvic Acids. http://www.humintech.com/pdf/humicfulvicacids.pdf

[10] Berglund, T. and Ohlsson, A.B. (1995) Defensive and Secondary Metabolism in Plant Tissue Cultures, with Special Reference to Nicotinamide, Glutathione and Oxidative Stress. Plant Cell, Tissue and Organ Culture, 43, 137-145.

[11] Chapman, H.O. and Pratt, P.E. (1978) Methods of Analysis for Soils, Plants and Water. Division of Agriculture Sciences University California, Berkley, 5-6.

[12] Lichtenthaler, H.K. and Buschmann, C. (2001) Chlorophylls and Carotenoids: Measurement and Characterization by UV-VIS Spectroscopy. In: Wrolstad, R.E., Acree, T.E., An, H., Decker, E.A., Penner, M.H., Reid, D.S., Schwartz, S.J., Shoemaker, C.F. and Sporns, P., Eds., Current Protocols in Food Analytical Chemistry (CPFA), John Wiley and Sons, New York, F4.3.1-F4.3.8.

[13] Larsen, P., Harbo, A., Klungron, S. and Ashein, T.A. (1962) On the Biosynthesis of Some Indole Compounds in Acetobacter Xylinum. Physiologia Plantarum, 15, 552-565. http://dx.doi.org/10.1111/j.1399-3054.1962.tb08058.x

[14] Danil, A.D. and George, C.M. (1972) Peach Seed Dormancy in Relation to Endogenous Inhibitors and Applied Growth Substances. Journal of the American Society for Horticultural Science, 17, 621-624.

[15] Homme, P.M., Conalez, B. and Billard, J. (1992) Carbohydrate Content, Fructose and Sucrose, Enzyme Activities in Roots, Stubble and Leaves of Rye Grass (Lolium perenne L.) as Affected by Source/Sink Modification after Cutting. Journal of Plant Physiology, 140, 282-291. http://dx.doi.org/10.1016/S0176-1617(11)81080-1

[16] Yemm, E.W. and Willis, A.J. (1954) The Respiration of Barley Plants. IX. The Metabolism of Roots during Assimilation of Nitrogen. New Phytologist, 55, 229-234. http://dx.doi.org/10.1111/j.1469-8137.1956.tb05283.X

[17] Herbert, D., Phipps, P.J. and Strange, R.E. (1971) Chemical Analysis of Microbial Cells. Methods in Microbiology, 5, 209-344. http://dx.doi.org/10.1016/S0580-9517(08)70641-X

[18] Smith, F., Gilles, M.A., Hamilton, J.K. and Godees, P.A. (1956) Colorimetric Method for Determination of Sugar Related Substances. Analytical Chemistry, 28, 350-356. http://dx.doi.org/10.1021/ac60111a017

[19] Bates, L.S., Waldren, R.P. and Reare, I.D. (1973) Rapid Determination of Free Proline for Water Stress Studies. Plant and Soil, 39, 205-207. http://dx.doi.org/10.1007/BF00018060

[20] Vartainan, N., Hervochon, P., Marcotte, L. and Larher, F. (1992) Proline Accumulation during Drought Rhizogenesis in Brassica napus var. Oleifera. Journal of Plant Physiology, 140, 623-628. http://dx.doi.org/10.1016/S0176-1617(11)80799-6

[21] Yemm, E.W., Cocking, E.C. and Ricketts, R.E. (1955) The Determination of Amino Acids with Ninhydrin. Analyst, 80, 209-214. http://dx.doi.org/10.1039/an9558000209

[22] Badford, M.M. (1976) A Rapid and Sensitive Method for the Quantitation of Microgram Quantities of Protein Utilizing the Principle of Protein Dye Binding. Analytical Biochemistry, 72, 248-254. http://dx.doi.org/10.1016/0003-2697(76)90527-3

[23] Snedecor, G.W. and Cochran, W.G. (1980) Statistical Methods. 7th Edition, the Iowa State University Press, Ames, IA. 
[24] Duncan, D.B. (1955) Multiple Range and Multiple F-Test. Biometrics, 11, 1-42. http://dx.doi.org/10.2307/3001478

[25] Huang, P.M., Wang, M.K. and Chiu, C.H. (2005) Soil Mineral-Organic Matter-Microbe Interactions: Impact on Biogeochemical Processes and Biodiversity in Soils. Pedobiologia, 49, 609-635.

[26] von Lutzow, M., Koegel-Knabner, I., Eckschmitt, E., Matzner, E., Guggenberger, G., Marschner, B. and Flessa, H. (2006) Stabilization of Organic Matter in Temperate Soils: Mechanism and Their Relevance under Different Soil Conditions. European Journal of Soil Science, 57, 426-445. http://dx.doi.org/10.1111/j.1365-2389.2006.00809.x

[27] Patil, R. (2010) Effect of Potassium Humate and Deproteinised Juice (DPJ) on Seed Germination and Seedling Growth of Wheat and Jowar. Annals of Biological Research, 1, 148-151.

[28] Peymaninia, Y., Valizadeh, M., Shahryari, R., Ahmadizadeh, M. and Habibpour, M. (2012) Relationship among Morpho-Physiological Traits in Bread Wheat against Drought Stress at Presence of a Leonardite Derived Humic Fertilizer under Greenhouse Condition. International Research Journal of Applied and Basic Science, 3, 822-830.

[29] Hassanein, R.A., Bassony, F.M., Barakat, D.M. and Khalil, R.R. (2009) Physiological Effects of Nicotinamide and Ascorbic Acid on Zea mays Plant Grown under Salinity Stress. 1-Changes in Growth, Some Relevant Metabolic Activities and Oxidative Defense Systems. Research Journal of Agriculture and Biological Sciences, 5, 72-81.

[30] El-Bassiony, H.M. (2005) Physiological Responses of Wheat to Salinity Alleviation by Nicotinamide and Tryptophan. Internationa Journal of Agriculture and Biology, 7, 653-659.

[31] Ferrara, G. and Brunetti, G. (2008) Foliar Applications of Humic Acids in Vitis vinifera L. cv Italia. J Int Sci Vigne Vin, 42, 79-87.

[32] Ameri, A. and Tehranifar, A. (2012) Effect of Humic Acid on Nutrient Uptake and Physiological Characteristic Fragaria x Ananassa Var: Camarosa. Journal of Biological Environment Science, 6, 77-79.

[33] Hathout, T.A., Shetawi, S.A. and Khallal, S.M. (1993) Effect of Mode of Application of Some Growth Regulators on the Physiology of Tomato Plants. III. Effect of Nicotinamide on Morphology Growth, Metabolism and Productivity. Egyptian Journal of Physiological Sciences, 17, 183-200.

[34] Taylor, S.E., Terry, N. and Huston, R.P. (1982) Limiting Factors in Photosynthesis. Plant Physiology, 10, $1541-1543$. http://dx.doi.org/10.1104/pp.70.5.1541

[35] Kalaichelvi, K., Chinnusamy, C. and Arul, S.A. (2006) Exploiting the Natural Resourse-Lignite Humic Acid in Agriculture. Agricultural Reviews, 27, 276-283.

[36] Pokorny, J. (2001) Introduction. In: Pokorny, J., Yanishlieva, N. and Gordon, M., Eds., Antioxidants in Food, Practical Applications, Woodhead Publishing Limited, Cambridge, 1-3. http://dx.doi.org/10.1533/9781855736160.1

[37] Lewis, N. and Yamamoto, E. (1990) Lignin: Occurrence, Biogenesis and Biodegradation. Annual Review of Plant Physiology and Plant Molecular Biology, 41, 455-496.

[38] Khattab, H. (2007) Role of Glutathione and Polyadenylic Acid on the Oxidative Defense Systems of Two Different Cultivars of Canola Seedlings Grown under Saline Condition. Australian Journal of Basic and Applied Sciences, 1, 323-334.

[39] Unlu, H., Unlu, H.O. and Karakurt, Y. (2010) Influence of Humic Acid on the Antioxidant Compounds in Pepper Fruit. Food, Agriculture and Environment, 8, 434-438.

[40] Serenella, N., Pizzeghelloa, D.A., Muscolob, N. and Vianello, A. (2002) Physiological Effects of Humic Substances on Higher Plants. Soil Biology and Biochemistry, 34, 1527-1536. http://dx.doi.org/10.1016/S0038-0717(02)00174-8

[41] Merlo, L., Ghisi, R., Rascio, N. and Passera, C. (1991) Effects of Humic Substances on Carbohydrate Metabolism of Maize Leaves. Canadian Journal of Plant Science, 71, 419-425. http://dx.doi.org/10.4141/cjps91-058

[42] Kodandaramaiah, J., Ven Katoramaiah, C., Gopala Rao, P. and Rao, K.N. (1984) Effect of Bgroup Vitamins on the Endogenous Cytokinin Levels of Clusterbeans Cyamopsis tetragonoloba L. Taub. Proceedings of the National Academy of Sciences (India), 54, 95-98.

[43] Farahat, M.M., Mazhar, A.A.M., Mona, H. and Mahgoub, M.H. (2012) Response of Khaya senegalensis Seedlings to Irrigation Intervals and Foliar Application of Humic Acid. Journal of Horticultural Science \& Ornamental Plants, 4, 292-298.

[44] Delavari, P.M., Baghizadeh, A., Enteshari, S.H., Kalantari, K.H.M., Yazdanpanah, A. and Mousavi, E.A. (2010) The Effects of Salicylic Acid on Some of Biochemical and Morphological Characteristic of Ocimum basilicucm under Salinity Stress. Australian Journal of Basic and Applied Sciences, 4, 4832-4845.

[45] Gzik, A. (1996) Accumulation of Proline and Pattern of $\alpha$-Amino Acids in Sugar Beet Plants in Response to Osmotic, Water and Salt Stress. Environmental and Experimental Botany, 36, 29-38. http://dx.doi.org/10.1016/0098-8472(95)00046-1

[46] Bandurska, H. (1993) In Vitro and in Vivo Effect of Proline on Nitrate Reductase Activity under Osmotic Stress in Barley. Acta Physiologiae Plantarum, 15, 83-88. 
[47] Harinasut, P., Srisunak, S., Pitukchaisopol, S. and Charoensataporn, R. (2000) Mechanisms of Adaptation to Increasing Salinity of Mulberry: Proline Content and Ascorbate Peroxidase Activity in Leaves of Multiple Shoots. ScienceAsia, 26, 207-211. http://dx.doi.org/10.2306/scienceasia1513-1874.2000.26.207

[48] Maggio, A., Migazaki, S.P., Veronese, T., Fujita, H.I., Ibeas, B., Damsz, M.L., Navasimhan, P.M., Joly, R.A. and Bressan, R.A. (2002) Does Proline Accumulation Play an Active Role in Stress Induced Growth Reduction? Plant Journal, 31, 699-712. http://dx.doi.org/10.1046/j.1365-313X.2002.01389.x

[49] Khaled, H. and Fawy, H.A. (2011) Effect of Different Levels of Humic Acids on the Nutrient Content, Plant Growth, and Soil Properties under Conditions of Salinity. Soil \& Water Research, 6, 21-29.

[50] Erik, B.G., Feiber, C., Shock, G. and Saundres, L.D. (2000) Evaluation of Humic Acid and Other Nonconventional Fertilizer Additiones for Onion Production. Malheur Experiment Station Oregon State University, Ontario, OR.

[51] Mahgoub, G.M.A., Khedr, E.A.F., Amer, S.M. and Faisal, R.I.I. (1991) Effect of Adenosine Triphosphate (ATP) and Nicotinamide Adenine Dinucleotide (NAD) on Maize Grain Yield and N-P-K Uptake in Grains. Annals of Agricultural Science, Moshtohor, 29, 631-644.

[52] Bozorgi, H.R., Pendashteh, M., Tarighi, F., Ziaei Doustan, H., Keshavarz, A.K., Azarpour, E. and Moradi, M. (2011) Effect of Foliar Zinc Spraying and Nitrogen Fertilization on Seed Yield and Several Attributes of Groundnut (Arachis hypogaea L.). World Applied Sciences Journal, 13, 1209-1217.

[53] Taiz, L. and Zeiger, E. (1998) Plant Physiology. Sinaur Associates Inc., Sunderland. 
Scientific Research Publishing (SCIRP) is one of the largest Open Access journal publishers. It is currently publishing more than 200 open access, online, peer-reviewed journals covering a wide range of academic disciplines. SCIRP serves the worldwide academic communities and contributes to the progress and application of science with its publication.

Other selected journals from SCIRP are listed as below. Submit your manuscript to us via either submit@scirp.org or Online Submission Portal.
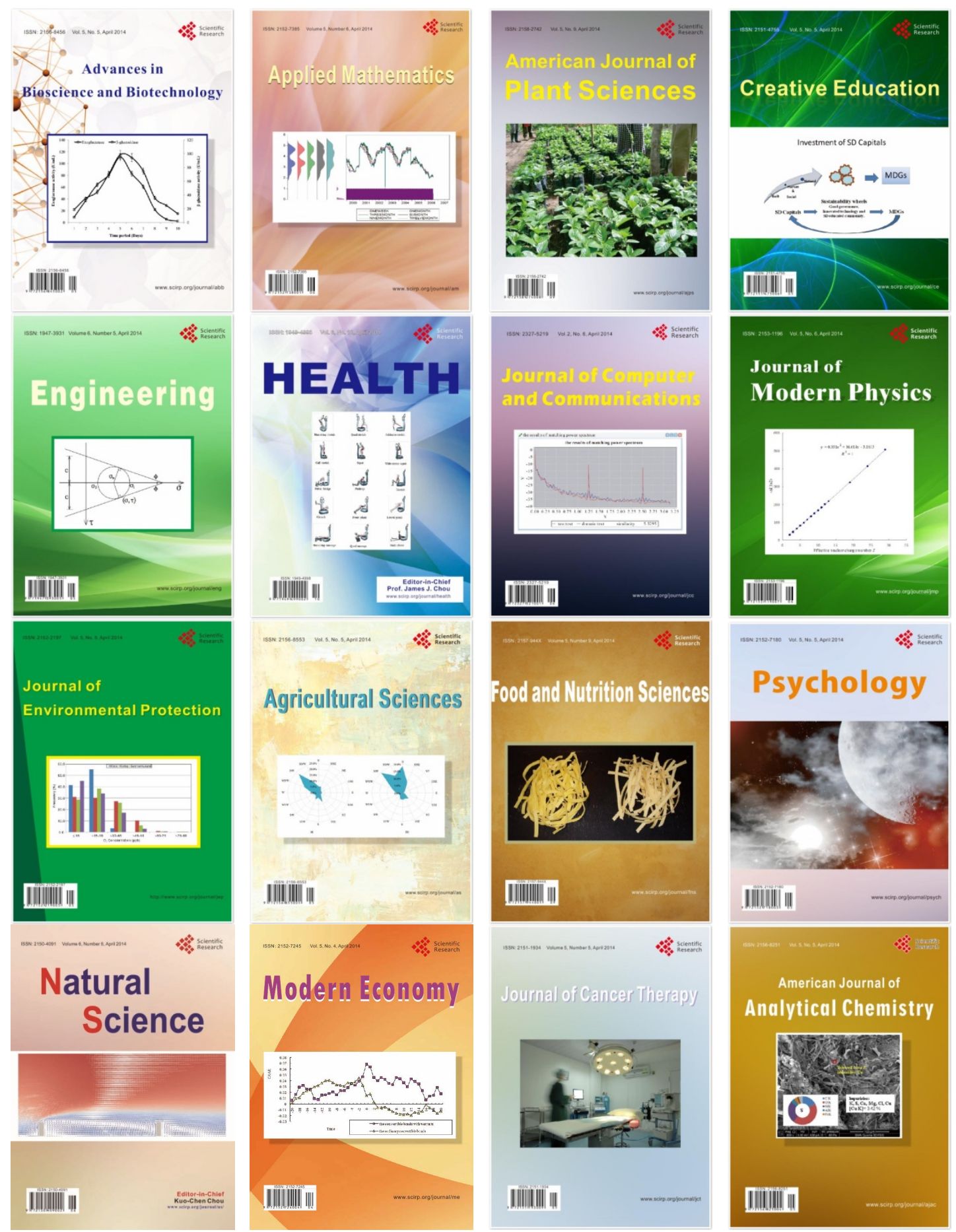